\title{
Effect Of Dietary Supplementation With Tigernut Tubers On Streptozotocin-Induced Diabetic Rats
}

\author{
H. A. Hassan \\ Department of Zoology, Faculty of Science, Mansoura University, Mansoura, Egypt.
}

\begin{abstract}
This work has been carried out to detect the effect of tigernut tubers as an antidiabetic plant on some biochemical parameters in streptozotocin (STZ)-induced diabetic rats. Diabetes mellitus was induced by a single intraperitoneal injection of $45 \mathrm{mg} \mathrm{STZ} / \mathrm{kg}$ body weight. The present results indicated an increase in both serum glucose level and liver glucose-6phosphatase (G6P) activity in STZ-diabetic rats. In addition, a significant decrease in serum insulin level and liver glycogen content was recorded in the same rats. Moreover, serum total lipids, total cholesterol, triglycerides and LDL-cholesterol levels revealed a significant increase, while a decrease in the level of HDL-cholesterol was observed in STZ-diabetic rats. The activity of serum aspartate aminotransferase (AST), alanine aminotransferase (ALT) and alkaline phosphatase (ALP) showed marked increase in STZ-diabetic rats. On the other hand, tigernutsupplemented diet $(25 \% \mathrm{w} / \mathrm{w})$ for two or four weeks recorded a significant improvement in all the above biochemical parameters affected by STZ injection especially after four weeks of treatment. Therefore, it was concluded that tigernut tubers had appreciable hypoglycemic and hypolipidemic effects on STZ-diabetic rats.
\end{abstract}

Key Words: Tigernut (Cyperus esculentus) - STZ-diabetic rats - lipid profiles

\section{Introduction}

Diabetes mellitus is one of the most common non-communicable world wide diseases. It is the major metabolic disorder characterized by insufficient insulin secretion and/or insensitive target tissues to metabolic actions of insulin (Motala et al., 2000., Pignone, 2007). Despite the progressive efforts to produce synthetic drugs for treating diabetic patients, there is a widespread propensity of patients to herbal medicine which can face the high cost and the poor availability for many rural populations, particularly in developing country (Marles and Fransworth, 1995., Somani et al., 2007). Recently, traditional plant medicines or herbal formulations to treat diabetes could form the basis for new treatments for the disease (Abdel-Monem, 2005; Brownlee, 2006., Rao, 2007). Also it might offer a natural key to unlock diabetic complications (Babu et al., 2006). In addition, the Egyptian herbal medicine was widely respected throughout the ancient Mediterranean world. Among these herbal remedies consumption of tigernut (yellow nutsedge) (Cyperus esculentus) is relatively popular in some societies as an antidiabetic agent (Gupta et al., 1971., Ghazanfar, 1994).

Tigernut tubers (Cyperus esculentus) are edible, with a slightly sweet and nutty flavor. The tubers are used as a foodstuff, particularly in Africa, where it's an important food crop with certain tribes. Tigernut have excellent nutritional qualities with a fat composition similar to olives (Coskunerm et al., 2002). It is also gluten and cholesterol free (Wills et al., 1980).

Moreover, it is the richest food source of flavonoids (El-Habashy, 1988) and also rich in water, fibers, alkaloids, digestible carbohydrates, saponins and fatty oils (glycerides), in addition to some elements, like phosphors, potassium, calcium, iron, zinc, magnesium and manganese (Addy and Eteshola, 1984; Jeong et al., 2000). The fatty oil content in tigernut was $25-27 \%$, these fatty acids classified into dominant saturated fatty acids such as miristic acid as well as dominant unsaturated fatty acids 
such as oleic acid, linoleic acid, palmic acid and stearic acid (Eteshola and Oraedu, 1996; Salem et al., 2005).

Chung et al. (1992) denoted that tigernut had marked therapeutic effects for intestinal metaplasia and hyperplasia and the animal experiments revealed no toxic effect, so safety guarantee was provided for its clinical application. In addition, it is considered as alterative, analgesic, antibacterial, antimalarial, antimicrobial, antipyretic, astringent, carminative, demulcent, diaphoretic, diuretic, hypoglycemic, hepatoprotective, hypotensive, stomachic, tonic and vermifuge (Gupta et al., 1971; Rahman and Zaman, 1989; Ghazanfar, 1994; Mehta et al., 1999). Also it exhibit anti-inflammatory properties upon inflammation, and immunostimulatory effects (Salem et al., 2005).

It was observed that there is a lack of experimental work on the beneficial effects of Egyptian tigernut. So the purpose of this study was to evaluate the hypoglycemic effect of tigernut tubers on STZ-induced experimental diabetes mellitus and its role in modulating the abnormal biochemical parameters associated with this disease.

\section{Material and methods}

\section{Materials:}

Streptozotocin (STZ) was purchased from Sigma company, USA. Tigernut tubers were obtained from the local market at Tanta city, Egypt. For the preparation of tigernut powder, the tubers were cleaned, washed and dried in a stream of hot air for an hour. The dried tubers were milled using a laboratory electric mill pass through a 40mesh sieve.

\section{Animals, experimental design and blood sampling:}

Male albino rats (Rattus rattus) weighing 160-180 $\mathrm{g}$ were used in this study. Animals were kept under good ventilation and received a balanced diet and water ad libitum through out the experiments. The standard diet consisted of casein $15.0 \%$, starch, $67.0 \%$, corn oil 8.0 $\%$, salt mixture $4.0 \%$, vitamin mixture 1.0 $\%$ and wood fiber $5.0 \%$ as reported by Ulloa et al. (1988). Experimental animals were divided into four main groups of six rats each, as follows:-

1- Control rats group: Rats of this group were injected intraperitonealy with a single dose of citrate buffer ( $\mathrm{PH} 4.5$ ) and considered as a control rats group.

2- Tigernut-fed rats group: These rats were received a balanced diet supplemented with $25 \%$ whole powder of tigernut tubers (experimental diet) (Salem et al., 2005). The average chemical composition (g/100g) of tigernut tubers includes starch 34 , oil 25 , protein 8 , sucrose 16 , fiber 10 and others 7. The diets were designed to contain equal amounts of energy (about $3606 \mathrm{Kcal} / \mathrm{Kg}$ diet) (Salem et al., 2005).

3- Diabetic rats group: The rats of this group were made diabetic by a single intraperitoneal injection of $45 \mathrm{mg} \mathrm{STZ}$ $/ \mathrm{kg}$ of body weight dissolved in citrate buffer ( $\mathrm{PH}$ 4.5) to overnight fasted animals (Ahmed, 2001). The rats with glucose level $180 \mathrm{mg} / \mathrm{L}$ or more were considered as STZ-diabetic rats.

4- Diabetic and tigernut-fed rats group: The diabetic rats were fed on tigernut supplemented diet $(25 \% \mathrm{w} / \mathrm{w})$.

After both treatment periods; two and four weeks, rats of each group were sacrificed. Blood samples were collected and the clear non-haemolised sera were quickly removed and stored at $-20{ }^{\circ} \mathrm{C}$ for subsequent biochemical measurements.

\section{Methods and techniques}

1-Serum levels of glucose, total lipids, total cholesterol, HDL-cholesterol and triglycerides were determined according to the methods of Trinder (1969), Frings et al. (1972), Allian et al. (1974), Burstein et al. (1970) and Fossati and Prencipe (1982), respectively, using kits from Diamond Diagnostic Chemical Company (Egypt).

2- Serum aminotransferases (AST and ALT)) enzymes activity was measured by the method described by Reitman and Frankel (1957), and alkaline phosphatase activity was determined depending on the method of Belfield and Goldberg, (1971) using a 


\section{H. A. Hassan}

commercially available reagent kits obtained from Randox Lab Ltd, U.K.

3-Serum LDL-cholesterol (LDL-C) level was calculated according to Friedewald (1972) formula:

LDL-C $=$ Total cholesterol concentration -

Triglyceride concentration - HDL-C concentration 5

4- Serum insulin level was measured using immuno-enzymatic assay Kits for the quantitative measurement of insulin in serum (Flier et al., 1979).

5- Liver glycogen content was estimated according to the technique of VanHandle (1965).

6- Glucose-6-phosphatase (G6P) activity was estimated depending on the method of Swanson (1955).

\section{Statistical analysis:}

The results obtained in the present study were evaluated by One Way ANOVA (analysis of variance) test and postcomparison was carried out with Tukey test. The results were expressed as mean \pm standard error and values of $\mathrm{P}<0.05$ were considered statistically significant (Snedecor and Cochran, 1982).

\section{Results}

As shown in Table 1, a single injection of streptozotocin (STZ) caused a significant increase in the level of serum glucose accompanied by a marked decrease in serum insulin and liver glycogen levels however the activity of liver G6P was significantly increased in STZ-diabetic rats. However, STZ-diabetic rats which were supplied with tigernut tubers for two experimental periods of treatment showed an improvement in these parameters.

Table 2 illustrates significant increases in serum total lipids, total cholesterol, LDL-cholesterol and triglycerides in STZ-diabetic rats, while a significant decrease in HDL-cholesterol was recorded. Meanwhile, the feeding on tigernut tubers-supplemented diet ameliorated the level of the mentioned lipid fractions especially after four weeks of treatment.

Table 3 shows the activity of liver enzymes such as AST, ALT and ALP which were increased in STZ-diabetic rats. However a significant decrease was noticed in these enzymes activity in STZ-diabetic groups that received tigernut tubers for two or four weeks. The observed ameliorative effect of tigernut supplemented diet was more pronounced after four weeks of the treatment.

Concerning ANOVA analysis of the investigated parameters it was revealed that the general effect between groups was significant $(\mathrm{P}<0.05)$ throughout the experiment. 
Table 1. Serum glucose and insulin levels, liver glycogen content and G6P enzyme activity in control and treated groups.

\begin{tabular}{|c|c|c|c|c|c|c|c|c|c|}
\hline & \multirow{3}{*}{ Parameters } & \multicolumn{7}{|c|}{ Animal Groups } & \multirow{3}{*}{$\begin{array}{c}\text { ANOVA } \\
\text { P }\end{array}$} \\
\hline & & \multirow[t]{2}{*}{ Control } & \multicolumn{2}{|c|}{$\begin{array}{l}\text { Tigernut } \\
\text { tuber }\end{array}$} & \multicolumn{2}{|c|}{ STZ-Diabetic } & \multicolumn{2}{|c|}{$\begin{array}{c}\text { STZ-Diabetic + Tigernut } \\
\text { tuber }\end{array}$} & \\
\hline & & & $2 \mathrm{wk}$ & $4 \mathrm{wk}$ & $2 \mathrm{wk}$ & $4 \mathrm{wk}$ & $2 \mathrm{wk}$ & $4 \mathrm{wk}$ & \\
\hline \multirow{4}{*}{ 志 } & \multirow[t]{2}{*}{$\begin{array}{l}\text { Glucose } \\
\text { mg/dl }\end{array}$} & 104.7 & 99.7 & 97.0 & 209.5 & 202.5 & 110.3 & 97.0 & \multirow{2}{*}{$P<0.05$} \\
\hline & & \pm 0.88 & \pm 0.88 & $\pm 0.81^{\mathrm{a}}$ & $\pm 1.31^{\mathrm{a}}$ & $\pm 1.18^{\mathrm{a}}$ & $\pm 0.98^{\mathbf{a b}}$ & $\pm 1.71^{\text {ac }}$ & \\
\hline & \multirow{2}{*}{$\begin{array}{c}\text { Insulin } \\
\mu \mathrm{U} / \mathbf{L}\end{array}$} & 4.2 & 4.4 & 4.5 & 2.4 & 2.5 & 3.4 & 3.7 & \multirow{2}{*}{$P<0.05$} \\
\hline & & \pm 0.08 & \pm 0.06 & $\pm 0.03^{\mathrm{a}}$ & $\pm 0.04^{\mathrm{a}}$ & $\pm 0.04^{\mathrm{a}}$ & $\pm 0.04^{\mathrm{ab}}$ & $\pm 0.08^{\mathrm{ac}}$ & \\
\hline \multirow{4}{*}{ 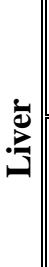 } & \multirow{2}{*}{$\begin{array}{c}\text { Glycogen } \\
\text { mg/100 g wt }\end{array}$} & 35.8 & 35.8 & 35.5 & 21.0 & 19.1 & 28.5 & 31.8 & \multirow{2}{*}{$\mathrm{P}<0.05$} \\
\hline & & \pm 0.41 & \pm 0.22 & \pm 0.18 & $\pm 0.13^{\mathrm{a}}$ & $\pm 0.21^{\mathrm{a}}$ & $\pm 0.23^{\mathrm{ab}}$ & $\pm 0.24^{\mathrm{ac}}$ & \\
\hline & G6P & 0.68 & 0.68 & 0.68 & 0.99 & 1.1 & 0.96 & 0.81 & \multirow[b]{2}{*}{$\mathrm{P}<0.05$} \\
\hline & $\begin{array}{c}\mu \mathrm{Mol} \mathrm{Pi} / \mathrm{min} / \mathrm{g} \\
\mathrm{wt}\end{array}$ & \pm 0.004 & \pm 0.003 & \pm 0.004 & $\pm 0.004^{\mathrm{a}}$ & $\pm 0.03^{\mathrm{a}}$ & $\pm 0.02^{\mathrm{a}}$ & $\pm 0.004^{\mathrm{ac}}$ & \\
\hline
\end{tabular}

Data are expressed as means \pm S.E. of six rats.

ANOVA: $\mathrm{P}=$ probability

Tukey test: $\mathrm{a}=$ significant difference as compared to control group.

$\mathrm{b}=$ significant difference as compared to STZ-diabetic group after $2 \mathrm{wk}$.

$\mathrm{c}=$ significant difference as compared to STZ-diabetic group after $4 \mathrm{wk}$.

Table 2. Serum total lipids, total cholesterol, triglycerides, HDL-C and LDL-C levels in control and treated groups.

\begin{tabular}{|c|c|c|c|c|c|c|c|c|}
\hline \multirow{3}{*}{ Parameters } & \multicolumn{7}{|c|}{ Animal Groups } & \multirow{3}{*}{$\begin{array}{c}\text { ANOVA } \\
\text { P }\end{array}$} \\
\hline & \multirow{2}{*}{ Control } & \multicolumn{2}{|c|}{$\begin{array}{l}\text { Tigernut } \\
\text { tuber }\end{array}$} & \multicolumn{2}{|c|}{ STZ-Diabetic } & \multicolumn{2}{|c|}{$\begin{array}{c}\text { STZ-Diabetic }+ \text { Tigernut } \\
\text { tuber }\end{array}$} & \\
\hline & & $2 \mathrm{wk}$ & $4 \mathbf{w k}$ & 2 wk & 4 wk & 2 wk & $4 \mathrm{wk}$ & \\
\hline \multirow{2}{*}{$\begin{array}{l}\text { Total lipids } \\
\text { mg/100 ml }\end{array}$} & 802 & 791 & 784 & 887 & 892 & 829 & 821 & \multirow{2}{*}{$P<0.05$} \\
\hline & \pm 1.7 & $\pm 1.8^{\mathrm{a}}$ & $\pm 1.4^{\mathrm{a}}$ & $\pm 1.1^{\mathrm{a}}$ & $\pm 1.1^{\mathrm{a}}$ & $\pm 0.88^{\mathrm{ab}}$ & $\pm 0.73^{\text {ac }}$ & \\
\hline \multirow{2}{*}{$\begin{array}{c}\text { Total } \\
\text { cholesterol } \\
\text { mg/100 ml }\end{array}$} & 99.3 & 94.8 & 90.7 & 140.3 & 148.7 & 121.0 & 114.0 & \multirow{2}{*}{$\mathrm{P}<0.05$} \\
\hline & \pm 0.80 & $\pm 0.60^{\mathrm{a}}$ & $\pm 0.49^{\mathrm{a}}$ & $\pm 0.76^{\mathrm{a}}$ & $\pm 0.76^{\mathrm{a}}$ & $\pm 0.76^{\mathrm{ab}}$ & $\pm 0.88^{\mathrm{ac}}$ & \\
\hline \multirow{2}{*}{$\begin{array}{l}\text { Triglycerides } \\
\text { mg/100 ml }\end{array}$} & 86.9 & 84.0 & 81.2 & 115.2 & 118.3 & 103.8 & 98.3 & \multirow{2}{*}{$\mathrm{P}<0.05$} \\
\hline & \pm 0.59 & \pm 0.58 & $\pm 0.31^{\mathrm{a}}$ & $\pm 1.1^{\mathrm{a}}$ & $\pm 1.2^{\mathrm{a}}$ & $\pm 1.2^{\mathbf{a b}}$ & $\pm 0.67^{\mathrm{ac}}$ & \\
\hline \multirow{2}{*}{$\begin{array}{c}\text { HDL-C } \\
\mathrm{mg} / 100 \mathrm{ml}\end{array}$} & 42.9 & 44.3 & 46.5 & 34.8 & 31.7 & 36.8 & 40.7 & \multirow{2}{*}{$P<0.05$} \\
\hline & \pm 0.60 & \pm 0.49 & $\pm 0.33^{\mathrm{a}}$ & $\pm 0.57^{\mathrm{a}}$ & $\pm 0.44^{\mathrm{a}}$ & $\pm 0.60^{\mathrm{a}}$ & $\pm 1.01^{\mathrm{ac}}$ & \\
\hline \multirow{2}{*}{$\begin{array}{c}\text { LDL-C } \\
\mathrm{mg} / 100 \mathrm{ml}\end{array}$} & 39.02 & 33.7 & 27.96 & 82.5 & 93.3 & 63.4 & 53.6 & \multirow{2}{*}{$P<0.05$} \\
\hline & \pm 0.90 & $\pm 0.85^{\mathrm{a}}$ & $\pm 0.37^{\mathrm{a}}$ & $\pm 0.59^{\mathrm{a}}$ & $\pm 0.56^{\mathrm{a}}$ & $\pm 0.47^{\mathbf{a b}}$ & $\pm 0.49^{\mathrm{ac}}$ & \\
\hline
\end{tabular}

Data are expressed as means \pm S.E. of six rats.

ANOVA: $\quad \mathrm{P}=$ probability

Tukey test: $\mathrm{a}=$ significant difference as compared to control group.

$\mathrm{b}=$ significant difference as compared to STZ-diabetic group after $2 \mathrm{wk}$.

$\mathrm{c}=$ significant difference as compared to STZ-diabetic group after $4 \mathrm{wk}$. 


\section{H. A. Hassan}

Table 3. Serum AST, ALT and ALP enzymes activity in control and treated groups.

\begin{tabular}{|c|c|c|c|c|c|c|c|c|}
\hline \multirow{3}{*}{ Parameters } & \multicolumn{7}{|c|}{ Animal Groups } & \multirow{3}{*}{$\begin{array}{l}\text { ANOVA } \\
\quad P\end{array}$} \\
\hline & \multirow[t]{2}{*}{ Control } & \multicolumn{2}{|c|}{$\begin{array}{l}\text { Tigernut } \\
\text { tuber }\end{array}$} & \multicolumn{2}{|c|}{ STZ-Diabetic } & \multicolumn{2}{|c|}{$\begin{array}{c}\text { STZ-Diabetic + Tigernut } \\
\text { tuber }\end{array}$} & \\
\hline & & $2 \mathrm{wk}$ & $4 \mathrm{wk}$ & $2 \mathrm{wk}$ & $4 \mathrm{wk}$ & $2 \mathrm{wk}$ & $4 \mathbf{w k}$ & \\
\hline \multirow{2}{*}{$\begin{array}{l}\text { AST } \\
\text { U/IL }\end{array}$} & 35.6 & 34.5 & 31.0 & 44.0 & 47.5 & 41.3 & 39.7 & \multirow{2}{*}{$\mathrm{P}<0.05$} \\
\hline & \pm 0.76 & \pm 0.43 & $\pm 0.37^{\mathrm{a}}$ & $\pm 0.83^{\mathrm{a}}$ & $\pm 0.43^{\mathrm{a}}$ & $\pm 0.49^{\mathbf{a b}}$ & $\pm 0.56^{\mathrm{ac}}$ & \\
\hline \multirow{2}{*}{$\begin{array}{l}\text { ALT } \\
\text { U/IL }\end{array}$} & 26.7 & 25.7 & 24.5 & 46.7 & 48.3 & 36.5 & 39.3 & \multirow{2}{*}{$P<0.05$} \\
\hline & \pm 0.39 & \pm 0.56 & \pm 0.43 & $\pm 0.49^{\mathrm{a}}$ & $\pm 0.49^{\mathrm{a}}$ & $\pm 0.76^{\mathrm{ab}}$ & $\pm 0.49^{\mathrm{ac}}$ & \\
\hline \multirow{2}{*}{$\begin{array}{c}\text { ALP } \\
\text { KArm } \\
\mu / 100 ~ \mathbf{~ m l}\end{array}$} & 118.4 & 114.0 & 112.8 & 148.8 & 155.8 & 130.5 & 125.0 & \multirow{2}{*}{$P<0.05$} \\
\hline & \pm 0.86 & $\pm 0.58^{\mathrm{a}}$ & $\pm 0.91^{\mathrm{a}}$ & $\pm 0.79^{a}$ & $\pm 0.60^{\mathrm{a}}$ & $\pm 0.43^{\mathrm{ab}}$ & $\pm 0.52^{\mathrm{ac}}$ & \\
\hline
\end{tabular}

Data are expressed as means \pm S.E. of six rats.

ANOVA: $\quad \mathrm{P}=$ probability

Tukey test: $\mathrm{a}=$ significant difference as compared to control group.

$\mathrm{b}=$ significant difference as compared to STZ-diabetic group after $2 \mathrm{wk}$.

$\mathrm{c}=$ significant difference as compared to STZ-diabetic group after $4 \mathrm{wk}$.

\section{Discussion}

In the present study, STZ-induced diabetic rats showed developed progressive increase in serum glucose level, which seems to be explained by deficient insulin secretion as a result of $\beta$-cell destruction by STZ (Santini et al., 1997; Szkudelski, 2001; Mazhar et al., 2005). However, it is now knowledged that when $\beta$-cell destruction is the primary cause of diabetes, insulin resistance in addition to deficient insulin secretion is thought also to be necessary for occurrence of hyperglycemia (Scoppola et al., 2001; Abdel-Monem, 2005). The biochemical basis of diabetes-induced insulin resistance could involve changes in glucose transporter number (Lillioja et al., 1988) or in insulin-induced activation of glycogen synthase, which reflect primarily depressed glycogen synthesis (Ortmeyer et al., 1994). This could provide explanation for the decreased ability of the liver to accumulate glycogen in the present and other diabetic studies (Margolis et al., 1985). However, in the present study it is more likely that the depleted hepatic glycogen stores could originate from the increased glycogenolysis as indicated by the presently increased G6P enzyme activity. In previous studies, the increased glycogenolysis was suggested to be responsible for the increase in hepatic glucose overproduction in diabetes (Venkatraman et al., 1991) and thus the increased blood glucose level (Pignone, 2007). However, the increase in gluconeogenesis in diabetes was also shown to play a determinant role in these phenomena (Beck-Nielsen et al., 1994). An explanation for the increased gluconeogenesis is that the state of insulin deficiency or insulin resistance in diabetes is almost associated with the relative insufficient tissue insulin suppression of lipolysis, which in turn may increase the rate of lipid oxidation. In association with these reportedly diabetesinduced changes in carbohydrate metabolism, various studies have demonstrated a general elevation in almost plasma lipid fractions that often coexist with hyperglycemia (Santini et al., 1997; Mazhar et al., 2005). Insulin can affect the adipocytes by inhibiting lipolysis and promoting storage of triglycerides in adipocytes (Zaahkouk, 2001). Thus, insulin lack in diabetes enhances hydrolysis of triglycerides into diglycerides, unesterified fatty acids and free glycerol (Ebara, 1994). These fatty acids may diffuse out of the cells or may be reesterified into triglycerides for storage or 
secretion of VLDL. Because insulin is known to suppress VLDL secretion, the lack of this suppression by deficient insulin secretion in diabetes may lead to hypertriglyceridemia, which possibly can mediate the mechanism by which diabetes causes hyperlipidemia (Saudek and Eder, 1979). As the concentration of triglycerides increases in the circulation, this increases the hydrolysis of triglycerides from VLDL, yielding LDL. These particles carry most of the cholesterol in the blood and are cleared mainly by the hepatic LDL receptor, which are increased by insulin (Saudek and Eder, 1979). Consequently, the clearance of LDL can be delayed resulting in hypercholesterolemia (Tsutsumi et al., 1995). In other words, the reduction in the rate of cholesterol removal from circulation appears responsible for hypercholesterolemia recognized in diabetic states. In this field of research, other data documented a marked increase of serum AST and ALT and ALP activities in diabetic animals (Eskander et al., 1995). These findings have further confirmed by Rawi et al. (1998). This elevation in enzymatic activities was attributed to their greater need for gluconeogenic substrates. Eskander et al. (1995) found that liver was necrotized in diabetic rats. Moreover, striking elevations of serum AST and ALT activities were observed in patients with acute hepatic necrosis. In addition, the elevation of the serum ALP activity in diabetic rat; may be attributed to the elevation of a small intestinal alkaline phosphatase activity in these animals (Unakami et al,, 1990; Mansour et al., 2002).

On the other hand, several medicinal plants, their extracts or different formulations have been given in the treatment of diabetes mellitus. The major merits of herbal medicines are their inherent efficacy, low incidence of side effects and low cost. Recently, Nutrition recommendation suggested that diet is the mainstay therapy in people with type 2diabetes, yet the ideal dietary guidelines for people with diabetes remain controversial (Somani et al., 2007). Recommendations aim to promote nutritional factors that have been shown to improve outcome, such as good glycemic control and maintaining ideal body weight, while reducing the risk of coronary heart disease through improved lipid profiles (Nutrition recommendation, 1999). Herbal botanical products have benefits for controlling diabetes beyond the inhibition of glucose absorption, including stimulating insulin secretion and/or action, improving insulin binding, improving capillary func-tion, and preventing poly unsaturated fatty acids (PUFA) peroxidation. (Broadhurst, 1997; Abdel Moneim, et al., 2001; Mansour et al., 2002; Babu et al., 2006).

The present results, on the other hand, demonstrated that the dietary supplementation with tigernut had an improving effect on the various metabolic disturbances associated with diabetes in rats. This is indicated by an improvement of glucose and insulin levels, concomitantly with increased hepatic glycogen content, indicating stimulated glucose utilization. Furthermore, the concentration of lipid fractions as well as liver function enzymes was found to be lowered near to normal values. These findings are agreement with the recent study of Raut and Gaikwad (2006) who suggested the hypoglycemic effect of tigernut on alloxan-diabetic rats. The observed metabolic improvements in the present study could contribute to the presence of the important nutritive agents of the tigernut tubers; polyunsaturated fatty acids (PUFAs). Epidemiological evidence and intervention studies clearly indicate the beneficial effects of polyunsaturated fatty acids (PUFAs) in diabetic state as well as in the prevention and treatment of long-term metabolic abnormalities associated with diabetes by the reduction of hyperlipidemia and hyperglycaemia (Merzouk and Khan, 2003 ; Ristic and Ristic, 2003; Rivellese and Lilli, 2003). The hypoglycemic effect of tigernut may be related to the ability of PUFAs to increase the number of insulin receptors, therefore increasing insulin activity. Similar results were seen by Das (1995) who suggested that feeding on high PUFAs diets can significantly affect insulin efficiency and glucose response in STZinduced diabetic rats. In addition, this antihyperglycemic activity may be attributed to the antioxidant activity of tigernut as it has the strong free radical scavenging action (Raut and Gaikwad, 2006). Furthermore, the antihyperglycemic 


\section{H. A. Hassan}

effect of tigernut may be due to its fibers and/or manganese contents (Abdel-Kader, 1986). Based on the results of Abdel-Barry et al. (1997) and Stillie et al. (2005), plants fibers-enriched diets cause delay in the absorption of carbohydrates from the diet thereby reducing blood glucose level. Also, it has been generally assumed that manganese has been shown to exert a hypoglycemic action in independent diabetic mellitus (IDDM) patients and it is now recognized as necessary co-factor for ATP phosphorylation of $\beta$-subunit of the insulin receptor (Reddy and King, 1987). The treatment with manganese salt resulted in a net increase in acute insulin response and the rate of glucose disappearance after glucose loading (White and Campell, 1993). Moreover, the present data revealed a hypocholesterolemic and hypolipidemic action of tigernut tubers. These data were agreement with previous studies (Salem et al., 2005). Also, our previous results suggested that dietary tigernut possesses considerable a hypocholesterolemic potential in both experimental aged rats (Hassan, 2005) and hypercholesterolemic rats (Hassan, 2006). The observed ameliorative effect of tigernut on lipid metabolism may be due to its poly unsaturated fatty acid contents. Diets enriched with poly unsaturated fatty acids have been recommended by several medical and nutritional aims because of the lipid lowering effects of PUFAs in the serum (An et al., 1995; Schmid and Woollett, 2003).

Also, tigernut administration could ameliorate the increase of serum enzymes activity through improvement of liver functions indicating its protective effect through conservation of glutathione; the main protective intracellular sulfhydryl peptide of the hepatocytes (Bamgbose et al., 1997; Mehta et al., 1999). Glutathione (GSH) plays an important role in protecting cells against oxidative stress by virtue of being a substrate for glutathione peroxidase and glutathione-S-transferase (Kurata et al., 1993). In addition, GSH disposes oxygen radical non-enzymatically (Wefers and Sies, 1983; Mosoni et al., 2004). Recently, several epidemiological studies and laboratory experimentation have yielded sound data and evidence in support of the fact that medicinal plants enhance the antioxidant defense against reactive oxygen species produced under hyperglycemic condition and this protects $\beta$-cells against loss, exhibit antidiabetic property and can attenuate the hazard effects of diabetes (Anuradha and Ravikumar, 2001; Badami and Channabasavaraj, 2007; Kumaran and Joel Karunakaran, 2007).

In conclusion, this study supports the concept that tigernut tubers exerted antihyperglycemic effects and consequently may alleviate liver dysfunction caused by STZ-induced diabetes, suggesting that the addition of this plant to the treatment protocols used for diabetic patients may improve diabetic therapy. However, further studies are also required to define the active ingredients of this promising plant. Taken together, the results of the present work highlight the nutritional benefits of tigernut in case of diabetes.

\section{References}

1. Abdel-Barry J A, Abdel-Hassan I A and Al-Hakiem M H H (1997): Hypoglycemic and anti-hyperlipidemic effects of Trigonella foenum-graecum leaf in normal and alloxan-induced diabetic rats. J. Ethnopharmacol., 58: 149-155.

2. Abdel-Kader M K (1986): Hypoglycemic Effect of Ambrosia maritima on Diabetic Rabbits.M.Sc. Thesis, Fac.Sci. Assuit Univ.

3. Abdel-Monem A A (2005): Hypoglycemic and hypolipidemic effects of green tea and Artemisla herba alba on streptozotocin diabetic rats. J. Egyp. Ger. Soc. Zool., 46 (A): 61-87.

4. Abdel-Moneim A A, Ahmed O M, Rawi $S M$ and Zimmler $M$ (2001): Studies on the hypoglycemic and hypolipidemic effects of glimepiride and some antidiabetic plants on streptozotocin diabetic rats. J. Egypt. Ger. Soc. Zool., 34(A): 175-206.

5. Addy E O and Eteshola E (1984): Nutritive value of a mixture of tigernut tubers (Cyperus esculentus L.) and baobab seeds (Adansonia digitata L.). J. Sci. of Food and Agric., 35(4): 437-440.

6. Ahmed O A (2001): Histopathological and biochemical evaluation of liver and kidney lesions in streptozotocin diabetic rats treated with glimepiride and various plant extracts. J.Union. Arab. Biol., 16(A): 585625 . 
7. Allain C C, Poon L S, Chan C S, Richmond $W$ and Fu $P$ C (1974): Enzymatic determination of total serum cholesterol. Clin. Chem., 20(4): 470-477.

8. An B K, Tanaka K and Ohtani S (1995): Effects of various n-3/n-6 fatty acid ratios in diet on lipid metabolism in growing chicks. Anim. Sci. Technol., 66: 630-840.

9. Anuradha C V and Ravikumar P (2001): Restoration on tissue antioxidants by fenugreek seeds (Trigonella Foenum Graecum) in alloxan-diabetic rats, Ind. J. Physiol. Pharmacol., 45(4): 408-420.

10. Babu P A, Suneetha1 G, Boddepalli1 R, Lakshmi1 V V, Rani1 T S, Babu Y R and Srinivas K (2006): A database of 389 medicinal plants for diabetes. Bioinformation, 1(4): 130-131.

11. Badami $\mathbf{S}$ and Channabasavaraj $\mathbf{K} \mathbf{P}$ (2007): In vitro antioxidant activity of thirteen medicinal plants of India's Western Ghats. Pharmaceutical Biol., 45(5): 392 396.

12. Bamgbose A M, Nwokoro S O, Kudi A C, Bogoro S, Egbo M L and Kushwaha S (1997): Effect of feeding tigernut (Cyperus rotundus, $L$ ) meal on the performance of rabbits. Trop. Anim. Health Prod., 29(1): 60-62.

13. Beck-Nielsen H, Hother-Nielsen O, Vaag A and Alford F (1994): Pathogenesis of type 2 diabetes mellitus (NIDDM): the role of muscle glucose uptake and hepatic glucose production in the development of hyperglycemia. Diabetologia, 37(2): 217221.

14. Belfield A and Goldberg D M (1971): Colorimetric method for determination of alkaline phosphatase. Enzyme (12): 561.

15. Broadhurst C L (1997): Nutrition and non-insulin dependent diabetes mellitus from an anthropological perspective. Alt. Med. Rev., 2(5):378-399.

16. Brownlee C (2006): Ancient Wisdom: Chinese extract may yield diabetes treatment. Science News, 169(23): 357.

17. Burstein M, Selvenick $\mathbf{H} \mathbf{R}$ and Morfin $\mathbf{R}$ (1970): Rapid method for the isolation of lipoproteins from human serum by precipitation with polyanions. J. Lipid Res., 11: 583-595.

18. Chung K, Chung H, Chieh H O and Chih $T$ (1992): Treatment of intestinal metaplasia and a typical hyperplasia of gastric mucosa with xiao wei yan powder. Chinese Medic., 12(10): 602-603.

19. Coskunerm Y, Ercan R, Karababa $\mathbf{E}$ and Nazlcan A N (2002): Physical and chemical properties of chufa (Cyperus esculentus L) tubers grown in the Çukurova region of Turkey. J. Sci. Food and Agric., 82(6): 625-631.

20. Das $U$ N (1995): Essential fatty acid metabolism in patients with essential hypertension, diabetes mellitus and coronary heart disease. Prostaglandins Leukot Essent. Fatty Acids, 52: 387-391.

21. Ebara H T, Mamo J C, Sakamaki R, Furukawa S, Nagano $S$ and Takahash $T$ (1994): Hyperlipidemia in streptozotocindiabetic hamsters as a model for human insulin deficient diabetes: comparison to streptozotocin-diabetic rats. Met. Clin. Exp., 43: 299-305.

22. El-Habashy I E M (1988): Taxonomical and Chemosystematic Studies on Cyperus (Cyperaceae) in Egypt. Ph. D. Thesis, Fac. Sci., Mansoura Univ., Pp. 254-258.

23. Eskander E F, Won Jun H, Ibrahim K A and Abdelal W E (1995): Hypoglycemic effect of an herbal formulation in alloxan diabetic rats. Egypt. J. Pharm. Sci., 36: 253-270.

24. Eteshola E and Oraedu A (1996): Fatty acid composition of tigernut tubers (Cyperus esculentus L.), baobab seeds (Adansonia digitata L.), and their mixture. J. Am. Oil Chemists Soci., 73 (2): 255257.

25. Flier J S, Kahn C R and Roth J (1979): Receptors, antireceptor antibodies and mechanisms of insulin resistance. N. Engl. J. Med., 300: 413-418.

26. Fossati $P$ and Prencipe L (1982): Serum triglycerides colourimetrically with an enzyme that produces hydrogen peroxide. Clin. Chem., 28(10): 2077-2088.

27. Friedewald $W \mathbf{T}$ (1972): Estimation of concentration of low-density lipoprotein cholesterol in plasma without use of the preparative ultracentrifuge. Clin. Chem., 18: 499-502.

28. Frings C S, Frendley T W, Dunn R T and Queen C A (1972): Improved determination of total serum lipids by the sulphovanillin reaction. Clin. Chem., 18(7): 673-674.

29. Ghazanfar S A (1994): CRC Handbook of Arabian Medicinal Plants. CRC Press, Inc., Boca Raton, FL. Pp. 265.

30. Gupta M B, Palit T K, Singh $\mathbf{N}$ and Bhargava K P (1971): Pharmacological studies to isolate the active constituents from Cyperus rotundus possessing antiinflammatory, anti-pyretic and analgesic activities. Ind. J. Med. Res., 59(1): 76-82.

31. Hassan H A (2005): Haematobiochemical changes induced by fed intake of edible tigernut (Cyperus esculentus) to senile 


\section{H. A. Hassan}

rats. J. Egypt. Ger. Soc. Zool., (48 A): 217-236.

32. Hassan H A (2006): Evaluation of therapeutic efficacy of tigernut (Cyperus esculentus) against expereimentally-induced hypercholesterolemia in male albino rats. Egypt. J. Zool., 47: 131-142.

33. Jeong S J, Miyamoto T, Inagaki M, Kim Y C and Higuchi R (2000): Rotundines A-C, three novel sesquiterpene alkaloids from Cyperus rotundus. J. Nat. Prod., 63(5): 673-675.

34. Kumaran A and Joel Karunakaran $\mathbf{R}$ (2007): Antioxidant activity of Cassia auriculata flowers. Fitoterapia, 78(1): 4647.

Kurata M, Suzuki M and Agar N (1993): Antioxidant systems and erythrocyte life span in mammals. Comp. Biochem. Physiol., 106 B(3): 477-487.

35. Lillioja S, Mott D, Howard $B$ and Bogardus (1988): Impaired glucose tolerance as a disorder of insulin and crosssectional in Pima Indians. N. Engl. J. Med., 318: 1217- 1225.

36. Mansour H A, Newairy A S, Yousef M I and Sheweita S A (2002): Biochemical study on the effects of some Egyptian herbs in alloxan-induced diabetic rats. Toxicol., 170(3):221-228.

37. Margolis R N, Selaway $\mathbf{H} \mathbf{P}$ and Curnow $R$ T (1985): Regulation of hepatic glycogen metabolism: Effects of diabetes, insulin infusion and pancreatic islet transplantation. Metabolism, 34: 62-68.

38. Marles $R$ T and Farnsworth N R (1995): Antidiabetic plants and their active constituents. Phytomedicine, 2: 137-189.

39. Mazhar F M, Moawad K M and AbdelGawad M H (2005): Evidence for a reversing effect of vitamin $\mathrm{E}$ or curcumin on some biochemical alterations associated with diabetes in pregnant rats and their fetuses. Egypt. J. Zool., 44: 367-388.

40. Mehta R S, Shankar M B and Varghase C D (1999): Evaluation of Cyperus rotundus for hepatoprotective activity. Ind. J. of Nat. Prod., 15(1): 13-17.

41. Merzouk $H$ and Khan N A (2003): Implication of lipids in macrosomia of diabetic pregnancy: can n-3 polyunsaturated fatty acids exert beneficial effects? Clin. Sci., 105(5): 519-529.

42. Mosoni L, Breuille D, Buffiere C, Obled $C$ and Mirand $P$ (2004): Age-related changes in glutathione availability and skeletal muscle carbonyl content in healthy rats. Exp. Gerontol, 39(2): 203-210.
43. Motala A A, Omar M A K and Pirie F J (2000): Type I diabetes mellitus in Africa: epidemiology and pathogenesis. Diabetes Int. J., 10:33-64.

44. Nutrition recommendations and principles for people with diabetes mellitus (1999): Diabetes Care, 22: S42S45.

45. Ortmeyer H K, Boodkin N L and Hansen B C (1994): Relationship of skeletal muscle glucose-6-phosphate to glucose disposal rate and glycogen synthesis activity in insulin resistant and non-insulin dependent diabetic Rhesus monkeys. Diabetologia, 37: 127-133.

46. Pignone M (2007): Initial oral therapy for patients with type 2 diabetes. Clin. Diabetes, 25: 64-65.

47. Rahman A U and Zaman K (1989): Medicinal plants with hypoglycemic activity, J. Ethnopharmacol., 26: 1-55.

48. Rao M S (2007): Medicinal plant species with potential antidiabetic properties. J. Sci. Food and Agric., 87(5): 743-150.

49. Raut N A, Gaikwad N J (2006): Antidiabetic activity of hydro/ethanolic extract of Cyperus rotundus in alloxan induced diabetes in rats. Fitoterapia, 7(7/ 8):585-788.

50. Rawi S M, Abdel Moneim A and Ahmed O M (1998): Studies on the effect of garlic and glibenclamide on alloxan-diabetic rats. 2: Biochemical effects. Egypt. J. Zool., 30: 211- 228.

51. Reddy S and King G L (1987): Insulin Receptor on Uptake the Diabetes. Annual (3), Alberti, K.G.M.M. Kial L.P., Eds. Amsterdam, Elsevier, Pp. 449-458.

52. Reitman $S$ and Frankel S (1957): A colorimetric method for the determination of serum glutamic oxaloacetic and glutamic pyruvic transaminase. Am. J. Clin., 28: 56-63.

53. Ristic V and Ristic G (2003): Role and importance of dietary polyunsaturated fatty acids in the prevention and therapy of atherosclerosis. Med. Pregl., 56: 50-53.

54. Rivellese A A and Lilli S (2003): Quality of dietary fatty acids, insulin sensitivity and type 2 diabetes. Biomed. Pharmacother., 57(2): 84-87.

55. Salem $\mathbf{L} M$, Zommara, $M$ and Imaizumi K (2005): Dietary supplementation with Cyperus esculentus L (tigernut) tubers attenuated atherosclerotic lesion in apolipoprotein E knockout mouse associated with inhibition of inflammatory cell responses. Am. J. Immuno. 1 (1): 60-67.

56. Santini S A, Marra G, Giardina B, Cotroneo P, Mordente A, Martorana G 
E, Manto A and Ghirlanda G (1997): Defective plasma antioxidant defenses and enhanced susceptibility to lipid peroxidation in uncomplicated IDDM. Diabetes, 46: 1853- 1858.

57. Saudek C D and Eder H A (1979): Lipid metabolism in diabetes mellitus. Am. J. Med., 66: 843-852.

58. Schmid K E and Woollett L A (2003): Differential effects of polyunsaturated fatty acids on sterol synthesis rates in adult and fetal tissues of the hamster: consequence of altered sterol balance. Am. J. Physiol. Gastrointest. Liver Physiol., 285(5G): 796803.

59. Scoppola A, Montechi F R, Mezinger G and Hala A (2001): Urinary mevalonate excretion rate in type 2 diabetes: Role of metabolic control. Atherosclerosis, 156: 357-361.

60. Snedecor G W and Cochran W G (1982): Statistical Methods $7^{\text {th }}$ Ed. The Stae University Press American, Iowa.

61. Somani R S, Jaina K S and Singhai A K (2007): Hypoglycemic activity of roots of Rubla cordifolla in normal and diabetic rats. Pharmacologyonline, 1: 162-169.

62. Stillie R, Bell R C and Field C J (2005): Diabetes-prone Biobreeding rats do not have a normal immune response when weaned to a diet containing fermentable fiber. Br. J. Nutr., 3(5): 645-653.

63. Swanson M A (1955): Glucose-6-phosphatase from liver. Methods Enzymol., 2: 541- 543.

64. Szkudelski T (2001): The mechanism of alloxan and streptozotocin action in $\beta$-cells of the rat pancreas. Physical Res., 50: 537546.

65. Trinder P (1969): A colorimetric method for the determination of glucose. Ann. Clin. Biochem., 6: 24-26.

66. Tsutsumi $\mathrm{K}$, Inoue $\mathrm{Y}$, Shime $\mathrm{A}$ and Murase T (1995): Correction of hypertriglyceridemia with low and high density lipoprotein cholesterol by the novel compound No. 1986, a lipoprotein lipase promoting agent in STZ-induced diabetic rats. Diabetes, 44: 414-417.

67. Ulloa J A, Valenica $\mathbf{M} \mathbf{E}$ and Garacia $\mathbf{Z}$ H (1988): Protein concentrates from chicpea: Nutritive value of a protein concentrate from chicpea (Cicer arietinum) obtained by ultrafiltration and its potential use in infant formula. J. Food Sci., 53(5): 1396-1398.

68. Unakami S, Komada T and Sakagishi Y (1990): Translocation of intestinal alkaline phosphatase in streptozotocin-induced diabetic rats. Int. J. Biochem., 22 (11): 13251330.

69. Van-Handle E (1965): Estimation of glycogen in small amounts of tissue. Anal. Biochem., 11: 256-262.

70. Venkatraman J T, Pehowich D, Rajotte R V, Thomson A B and Clandinin M T (1991): Effect of dietary fat on diabetesinduced changes in liver microsomal fatty acid composition and glucose-6-phosphatae activity in rats. Lipids, 26: 441-444.

71. Wefers $H$ and Sies $H$ (1983): Oxidation of glutathione by superoxide radical to the disulfide and sulfonate yielding singlet oxygen. Eur. J. Biochem., 137: 29-36.

72. White J R and Campell R K (1993): Magnesium and diabetes: A review. Ann. Pharmacother., 27: 775-780.

73. Wills G D, Hoagland R E and Paul R N (1980): Anatomy of yellow nutsedge (Cyperus esculentus). Weed Science, 28: 432-437.

74. Zaahkouk S A (2001): Studies on the effect of some antidiabetic plants (Lupinus termis) and (Trigonella foenum gracium) seeds extract on some physiological aspects of STZ-diabetic rats. J. Union Arab. Biol., 16 (A): 447-470. 


\title{
تأثير وجبة غذائية مدعمة بدرنات حب العزيز على الجرذان المصابة بمرض السكر المستحدث بالستريتوزوتوسين الجين
}

\author{
هناء على حسن \\ قسم علم الحيوان ـ كلية العلوم ـ جامعة المنصورة
}

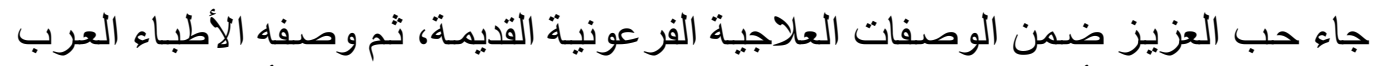

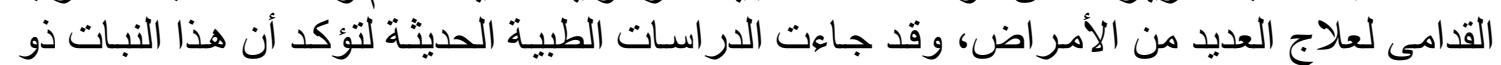

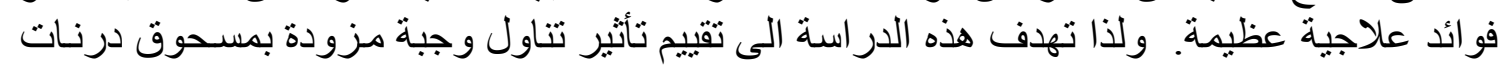

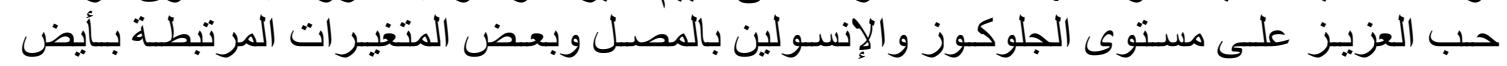

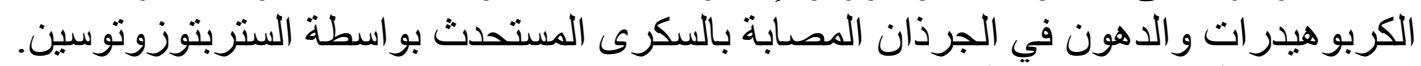

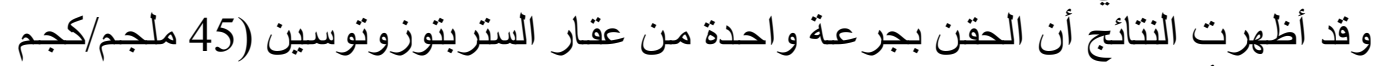

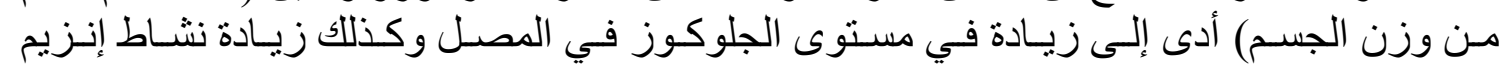

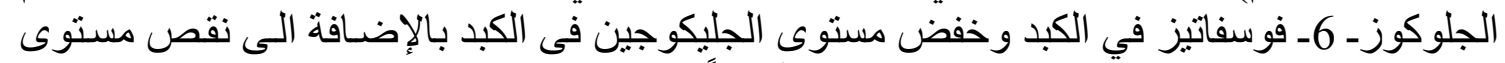

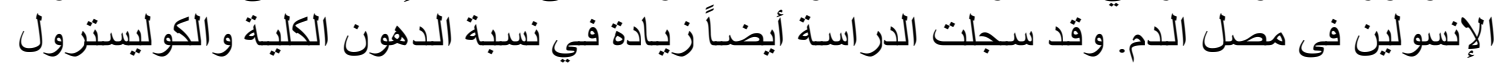

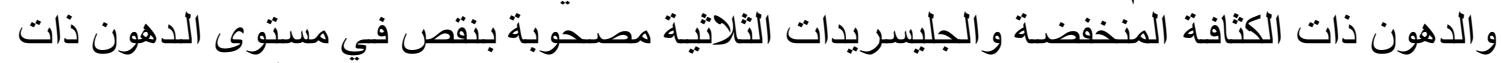

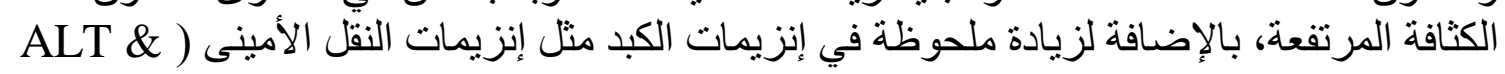

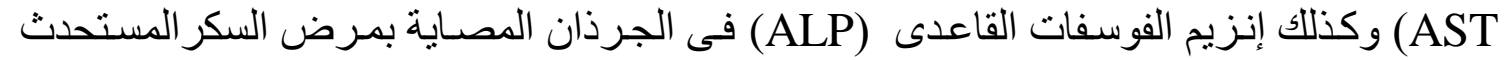

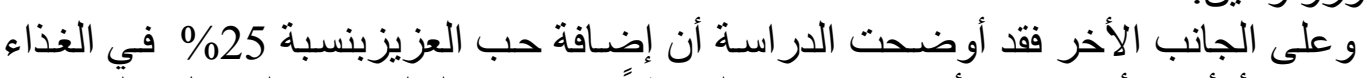

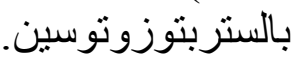

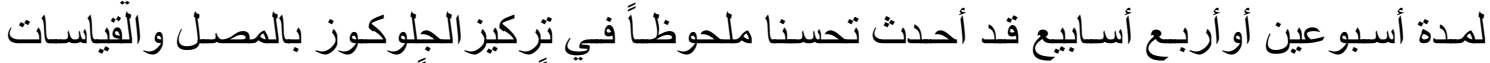

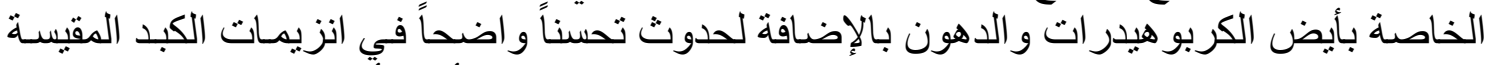

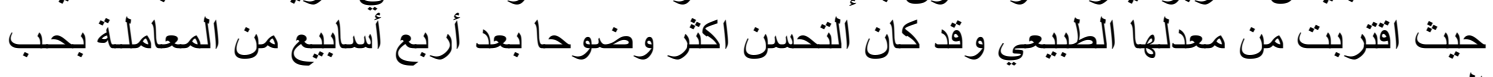

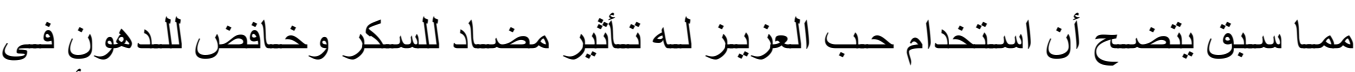

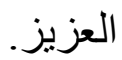

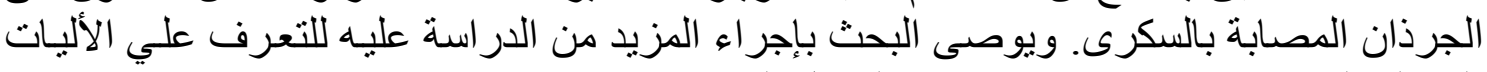
المختلفة له ومدى إمكانية استخدامه في المجال الطبى. 